\title{
Rancang Bangun DC-DC Konverter 300 Volt Jenis Buck Konverter
}

\author{
Rifdian I.S ${ }^{1}$ \\ 1)Program Studi DIII Teknik Listrik Bandar Udara \\ Politeknik Penerbangan Surabaya \\ Jl. Jemur Andayani I/73 Wonocolo Surabaya 60236 \\ Email : rifdian.anto@gmail.com
}

\begin{abstract}
Abstrak
DC chopper jenis buck dengan beberapa aplikasi telah banyak dibuat. Namun dalam penelitian tersebut hanya menggunakan tegangan masukan yang dturunkan terlebih dahulu oleh trafo step down. Selain itu, dalam beberapa penelitian dengan DC chopper buck tidak pernah memperhitungkan seberapa besar pengaruh efek parasitik terhadap tegangan keluaran yang dibutuhkan. Komponen pensakla ran yang digunakan dalam beberapa penelitian juga tidak dibahas secara mendalam. Dari beberapa topologi konverter arus searah, konverter jenis buck dipilih karena konverter ini menghasilkan tegangan keluaran yang memiliki nilai maksimal sama dengan tegangan masukan Selain itu, buck converter memiliki efisiensi yang tinggi dan riak pada tegangan keluaran yang rendah. Dalam penelitian ini akan dibahas respon DC Chopper Buck dengan catu daya utama tegangan AC jala-jala satufasa yang disearahkan yang meliputi tegangan masukan, arus masukan, tegangan keluaran, arus keluaran, dan efisiensi. Berdasarkan hasil pengujian, tegangan yang digunakan untuk mensuplai DC Chopper buck ini sebe sar 300 Volt dengan variasi beban resistif dan beban dominan induktif. Variasi beban resistif yang

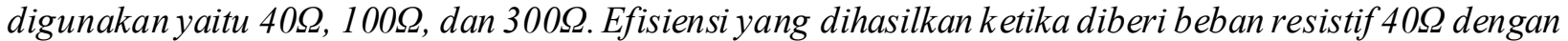

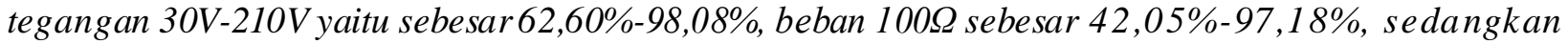
pada beban $300 \Omega$ efisiensi yang dihasilkan sebesar $37,32 \%-90,90 \%$.
\end{abstract}

Kata Kunci : DC Chopper buck, beban resistif, beban induktif.

\section{PENDAHULUAN}

Di era modern seperti sekarang ini, penggunaan catu daya DC mulai dari skala tegangan rendah, tegangan menengah sampai tegangan tinggi semakin banyak. Akibat penggunaan catu daya DC yang semakin banyak maka diperlukan suatu sistem yang dapat mengkonversi tegangan DC dari suatu tingkat tegangan ke tingkat tegangan lain, seperti halnya transformator dalam system AC. Sistem ini harusdapat bekerja secara efisien sehingga tegangan keluarannya memiliki kualitas yang baik.

Salah satu cara untuk mengkonversikan tegangan DC ke tegangan DC yang lebih rendah adalah dengan menggunakan rangkaian DC chopper jenis Buck. Ada dua metode yang biasanya digunakan dalam mengatur tegangan keluaran pada DC chopper jenis buck, yaitu dengan operasi hard switching dan soft switching. Pada penelitian ini penulis menggunakan operasi hard switching untuk mengatur tegangan keluarannya yaitu dengan mengatur besar lebar pulsa (duty cycle) dari rangkaian kontrol PWM (Pulse Width Modulation).

Dalam beberapa penelitian sebelumnya $[8,9,12,13]$, DC chopper jenis buck dengan beberapa aplikasi telah banyak dibuat. Namun dalam penelitian tersebut hanya menggunakan tegangan masukan dibawah 50 Volt. Selain itu, dalam beberapa penelitian dengan DC chopper buck

$[8,9,12,13]$ tidak pernah memperhitungkan seberapa besar pengaruh efek parasitik terhadap tegangan keluaran yang dibutuhkan. Komponen pensaklaran yang digunakan dalam beberapa penelitian juga tidak dibahas secara mendalam. Berdasarkan pada hal tersebut, Penulis akan merancang sebuah modul DC chopper buck dengan tegangan masukan 300VDC dengan 
melihat respon yang terjadi seperti pengaruh yang ditimbulkan terhadap MOSFET. Dalam tugas akhir ini juga membahas tentang pengaruh efek parasitik terhadap tegangan keluaran. Dalam Tugas Akhir ini Penulis memilih rangkaian DC chopper jenis buck karena memiliki efisiensi yang tinggi,

rangkaiannya sederhana, tidak memerlukan transformator sebagai sumber tegangan masukannya, tingkat stress pada komponen switching yang rendah, riak (ripple) pada tegangan keluaran juga rendah sehingga penyaring atau filter yang dibutuhkan pun relatif kecil. Untuk penggunaan rangkaian kontrol dengan IC TL494 dipilih karena IC TL494 dapat mengatur frekuensi dan duty

cycle. Selain itu perancangan dan pembuatannya pun lebih sederhana dibandingkan dengan mikroprosesor. MOSFET digunakan sebagai piranti pensaklaran, karena MOSFET sangat cocok bekerja pada switching frekuensi tinggi dan basis drivernya adalah tegangan sehingga mudah dalam pembuatan rangkaian pemicuannya. Hasil dari penelitian rangkaian DC chopper jenis buck ini diharapkan dapat digunakan sebagai penurun tegangan DC yang lebih efektif dan efisien sesuai kebutuhan.

\section{METODE}

Perancangan tugas akhir ini terdiri dari rangkaian penyearah (rectifier), rangkaian DC Chopper buck, rangkaian kontrol PWM, rangkaian mosfet driver. Blok diagramnya ditunjukkan pada Gambar 1 dibawah ini.

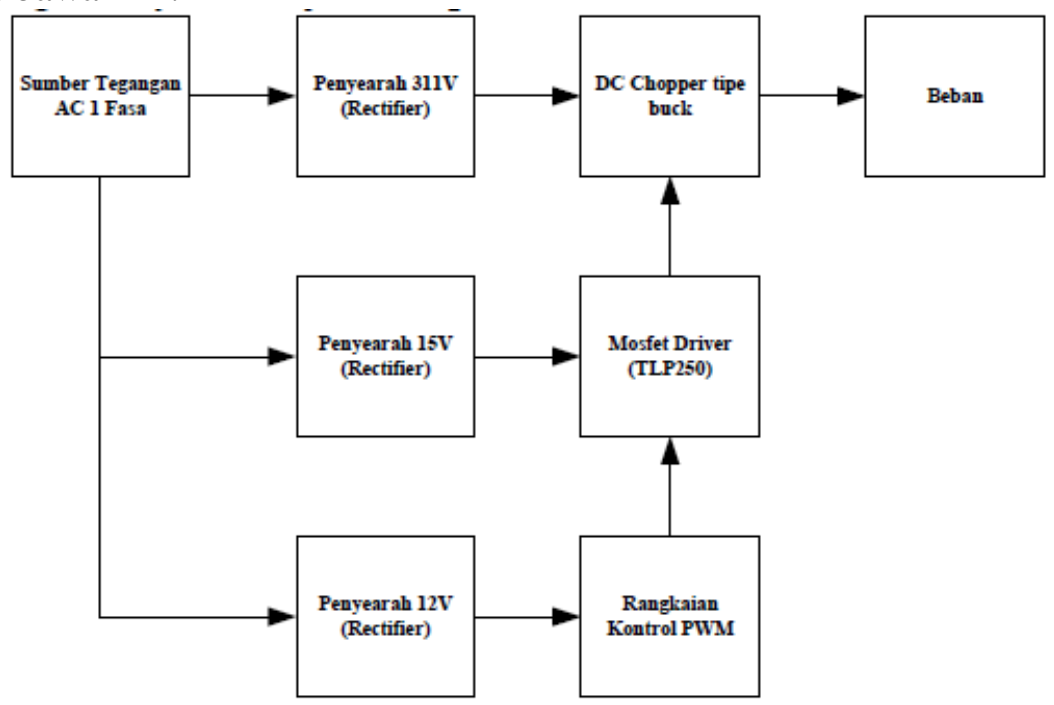

Gambar 1. Blok Diagram Rancangan

\section{RANCANGAN PENYEARAH}

Rangkaian penyearah gelombang penuh terdiri dari diode bridge KBPC3510 dan kapasitor yang tertera pada Gambar 2 berikut ini.

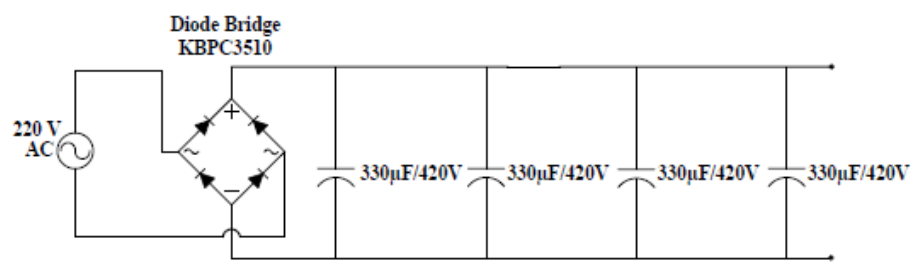

Gambar 2. Penyearah gelombang penuh satu fasa 
Rangkaian ini merupakan sumber DC 311 Volt yang digunakan untuk mensuplai $D C$ Chopper Buck. Tegangan DC 311 Volt didapatkan dari tegangan AC jala-jala yang sebelumnya disearahkan oleh dioda bridge.

Pada rangkaian ini terdapat penyearah satu fasa dengan $\mathrm{CT}$, dioda, regulator tegangan, kapasitor, resistor dan LED seperti yang tertera pada Gambar 3.

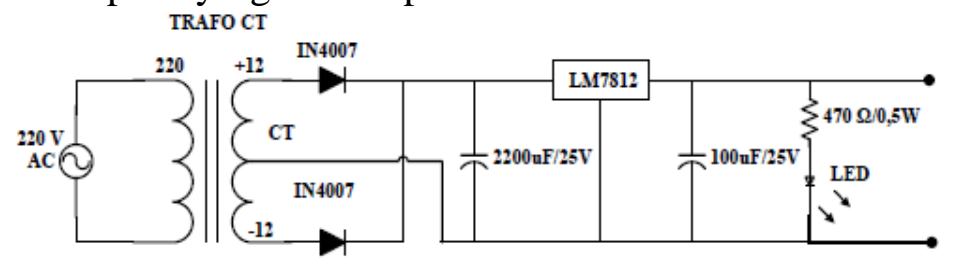

Gambar 3. Penyearah gelombang penuh 1 fasa dengan CT

Rangkaian ini merupakan sumber tegangan DC 12 Volt. Tegangan 12 VDC berfungsi sebagai suplai untuk rangkaian kontrol PWM dan kipas. Tegangan DC didapatkan dari hasil penyearahan tegangan AC jala-jala yang sebelumnya diturunkan menggunakan trafo stepdown. Tegangan DC selanjutnya diteruskan ke IC Regulator LM7812. LED pada penyearah digunakan untuk indikator rangkaian penyearah bekerja.

\section{CHOPPER BUCK}

DC Chopper yang digunakan pada penelitian ini adalah DC Chopper topologi buck yang mempunyai karakteristik nilai tegangan keluaran lebih kecil dari nilai tegangan masukan. $D C$ Chopper Buck terdiri dari beberapa komponen penyusun yaitu kapasitor, induktor, MOSFET dan dioda yang tersusun seperti pada Gambar 4.

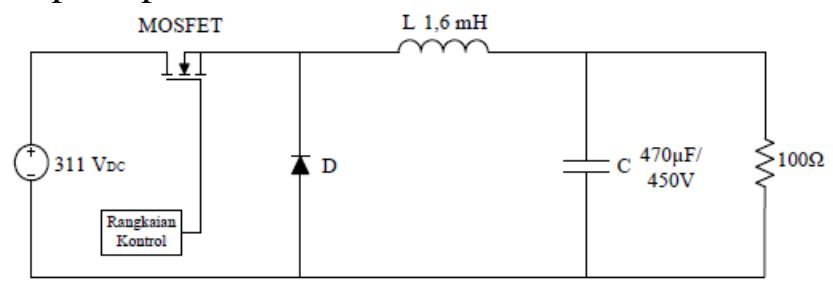

Gambar 4. Skema DC Chopper tipe Buck

Komponen penyusun perlu dihitung nilai minimalnya agar DC Chopper Buck dapat bekerja sesuai yang diinginkan. Penentuan spesifikasi awal juga dilakukan berdasarkan ketersediaan komponen yang mudah didapat dan kemampuan komponen berdasarkan datasheet. Spesifikasi DC Chopper Buck yang akan dibuat adalah sebagai berikut :

- Tegangan masukan : $311 \mathrm{Vdc}$

- Frekuensi Switching : $15 \mathrm{kHz}$

- Kapasitor

Kapasitor merupakan media untuk memindahkan daya ke beban. Nilai $\mathrm{C}$ minimal:

$$
\begin{aligned}
C & =\frac{V_{o}(1-D)}{8 L \Delta V_{o} f_{s}^{2}} \\
= & \frac{220(1-0.7)}{\mathbf{8 x 0 . 0 0 1 \times 0 . 2 2 \times 1 5 0 0 0 ^ { 2 }}} \\
= & \frac{66}{396000}=166 \mu \mathrm{F}
\end{aligned}
$$


Namun untuk mengurangi noise, nilai kapasitansi kapasitor yang dipasang diperbesar menjadi $470 \mu \mathrm{F} / 450 \mathrm{~V}$.

- Induktor

Pada perancangan buck converter ini digunakan beban sebesar $100 \Omega$. Dengan demikian induktor minimal dapat dihitung menggunakan Persamaan sebagai berikut:

$$
\begin{aligned}
\operatorname{Lmin} & =\frac{(1-D) R}{2 \mathrm{fs}} \\
& =\frac{(1-0,7) 100}{2.15000}=1 \mathrm{mH}
\end{aligned}
$$

Nilai Lmin inilah yang digunakan pada perancangan untuk rangkaian buck.

\section{HASIL DAN ANALISA}

Sumber tegangan yang digunakan pada tugas akhir ini yaitu tegangan satu fasa yang berasal dari jala-jala. Berikut adalah titik pengukuran tegangan AC masukkan 220 volt.

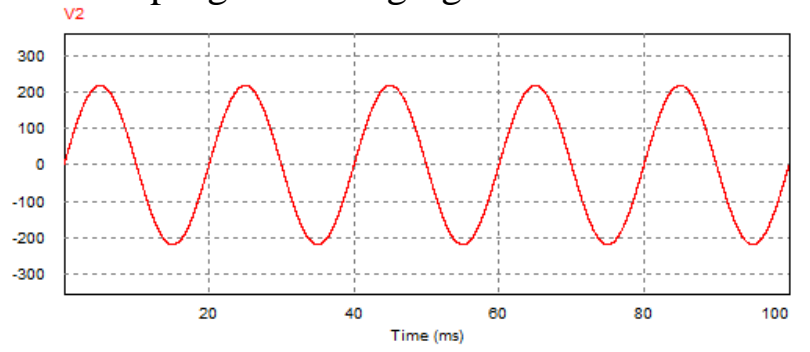

Gambar 5. Tengan input AC 220V

Dari gambar di atas diperoleh :

$$
\begin{aligned}
\mathrm{V}_{\mathrm{p}} & =2,98 \operatorname{div} \times 10 \mathrm{~V} / \operatorname{div} \times 10 \\
& =298 \text { Volt }
\end{aligned}
$$

Tegangan efektif :

Vrms $=\frac{V p}{\sqrt{2}}=\frac{300}{\sqrt{2}}=212$ volt

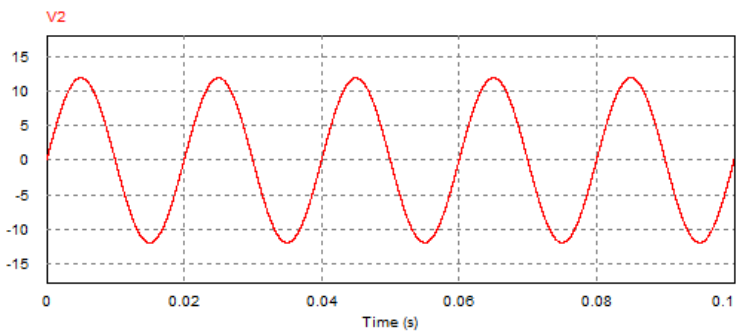

Gambar 6. Gelombang keluaran AC $12 \mathrm{~V}$ tanpa beban

Tabel 2 Pembacaan pengukuran tegangan menggunakan osiloskop dan multimeter digital

\begin{tabular}{ccc}
\hline Parameter & \multicolumn{2}{c}{ Nilai } \\
\hline Penyearah & Osiloskop $\left(\mathrm{V}_{\mathrm{AC}}\right)$ & Multimeter $\left(\mathrm{V}_{\mathrm{AC}}\right)$ \\
Tanpa beban & 11,51 & 11,41 \\
\hline
\end{tabular}


Pada Tabel 2 terlihat bawa nilai tegangan pada pengukuran menggunakan osiloskop dan pembacaan nilai tegangan pada multimeter menunjukan nilai yang hampir sama. Perbedaan tegangan ini dapat disebabkan karena beberapa faktor yaitu fluktuasi tegangan jala-jala PLN

saat dilakukan pengukuran yang berbeda. Perbedaan nilai tersebut tidak terlalu berpengaruh pada sistem sehingga rangkaian penyearah dianggap mampu untuk menyuplai pemyearah Center Tap.

\section{PENGUJIAN RANGKAIAN DC CHOPPER BUCK}

Pada pengujian rangkaian DC Chopper ini dilakukan 3 pengujian yang meliputi pengujian kerja MOSFET IRFP460, pengujian DC Chopper beban resistif (R), dan pengujian DC Chopper beban dominan induktif $(\mathrm{R}+\mathrm{L})$. Frekuensi yang digunakan pada pegujian ini $15 \mathrm{KHz}$.

\section{Pengujian Kinerja MOSFET IRP460}

Pengujian suhu kerja MOSFET dilakukan dengan mengamati perubahan suhu MOSFET pada saat switching.

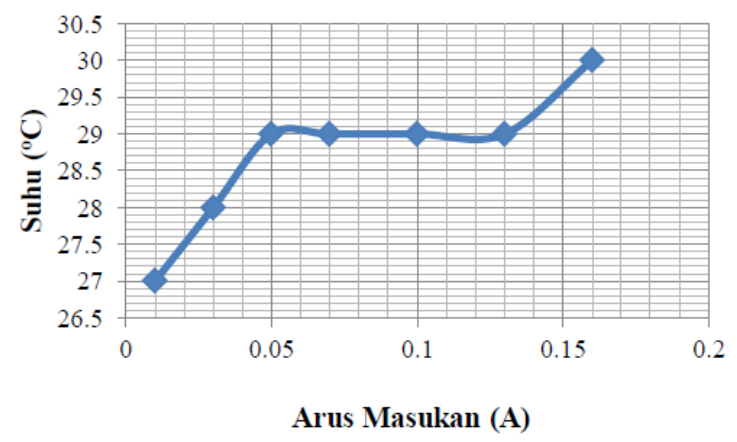

Gambar 7. Grafik Perbandingan Arus Masukan dengan suhu

Berdasarkan datasheet, MOSFET IRFP460 dapat bekerja pada suhu -55 - 150 oC. Meskipun terjadi peningkatan arus masukan, tetapi tidak terjadi peningkatan suhu yang signifikan. Dapat disimpulkan bahwa MOSFET IRFP460 memiliki spesifikasi yang cukup untuk kebutuhan DC

Chopper Buck.

\section{Pengujian DC Chopper Buck beban resistif}

Pengujian yang dilakukan bertujuan untuk mengetahui tegangan masukan, tegangan keluaran, arus masukan dan arus keluaran dari buck converter pada saat dibebani beban resistif.

Tabel 3 Hasil pengujian DC Chopper Buck dengan beban resistif

\begin{tabular}{ccccc}
\hline Duty cycle $(\%)$ & Vin $(\mathrm{V})$ & lin $(\mathrm{A})$ & Vout $(\mathrm{V})$ & lout $(\mathrm{A})$ \\
\hline 10 & 298 & 0,01 & 31,2 & 0,08 \\
20 & 297,7 & 0,03 & 60,3 & 0,14 \\
30 & 297,4 & 0,05 & 90 & 0,16 \\
40 & 297,2 & 0,07 & 120 & 0,17 \\
50 & 297 & 0,10 & 150,6 & 0,19 \\
60 & 296,8 & 0,13 & 180,2 & 0,21 \\
70 & 296,6 & 0,16 & 209,3 & 0,22 \\
\hline
\end{tabular}




\section{Pengujian Parasitik pada beban resistif}

Tabel 5 Perubahan nilai resistansi pada simulasi

\begin{tabular}{|c|c|c|c|c|c|c|c|}
\hline \multirow{2}{*}{$\begin{array}{c}\text { Duty } \\
(\%)\end{array}$} & \multicolumn{2}{|c|}{ Nilai Nyata } & \multicolumn{2}{|c|}{ Nilai Asumsi } & \multicolumn{3}{|c|}{ Tegangan Keluaran (V) } \\
\hline & $\begin{array}{c}R \\
(\Omega)\end{array}$ & $\begin{array}{c}\mathrm{L} \\
(\mathrm{mH})\end{array}$ & $\begin{array}{c}R \\
(\Omega)\end{array}$ & $\underset{(\mathrm{mH})}{\mathrm{L}}$ & $\begin{array}{c}\text { V } \\
\text { ukur }\end{array}$ & Teoritik & Parasitik \\
\hline 10 & 2,77 & 1,6 & 200 & 1,6 & 31,2 & 29,79 & 30,7 \\
\hline 20 & 2,77 & 1,6 & 200 & 1,6 & 60,3 & 59,54 & 60 \\
\hline 30 & 2,77 & 1,6 & 200 & 1,6 & 90 & 89,21 & 90,9 \\
\hline 40 & 2,77 & 1,6 & 200 & 1,6 & 122 & 118,87 & 121,2 \\
\hline 50 & 2,77 & 1,6 & 200 & 1,6 & 150,6 & 148,5 & 150,8 \\
\hline 60 & 2,77 & 1,6 & 200 & 1,6 & 180,2 & 178,05 & 179,8 \\
\hline 70 & 2,77 & 1,6 & 200 & 1,6 & 209,3 & 207,62 & 209 \\
\hline
\end{tabular}

Tabel 5 menunjukan perbandingan nilai tegangan antara hasil pengukuran, simulasi teoritik dan parasitik. Selisih nilai tegangan ini terjadi akibat nilai-nilai resistansi parasitik yang terdapat pada tiap titik komponen, terutama komponen $\mathrm{L}$ dan jalur konduksi ketika rangkaian dioperasikan secara bersama.

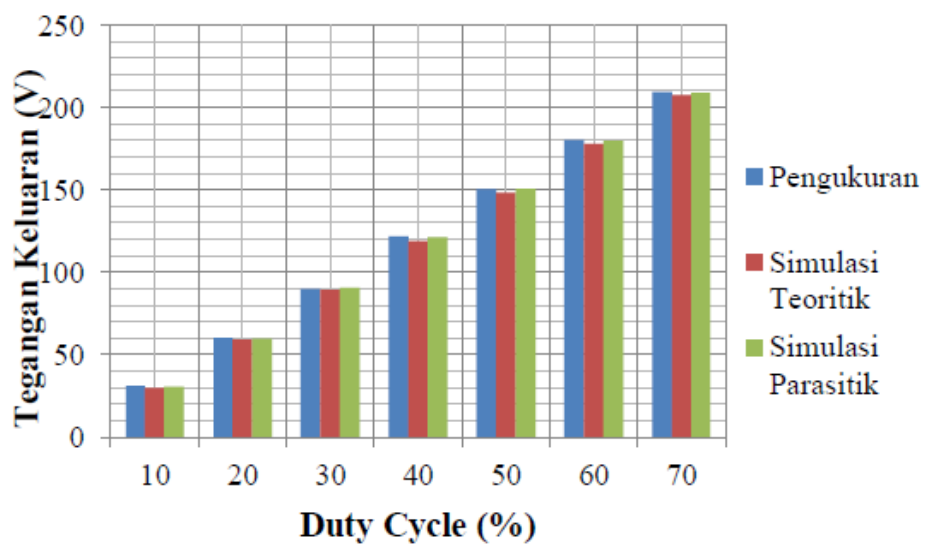

Gambar 8. Grafik perbandingan nilai tegangan pengukuran, simulasi dan teori parasitic

Dari Gambar 8 dapat dilihat bahwa antara nilai pengukuran, simulasi teorik, dan simulasi parasitik sudah saling mendekati atau cenderung sama.

\section{Pengujian efisiensi DC Chopper Buck beban dominan resistif}

Efisiensi DC Chopper Buck dapat dicari dengan cara menghitung perbandingan daya input (Pin) dan daya output (Pout) pada DC Chopper Buck pada masing - masing percobaan, dengan menggunakan persamaan berikut :

$$
\begin{aligned}
& \eta=\frac{P_{\text {out }}}{P_{\text {in }}} \times 100 \% \\
& \text { Dimana: } \\
& P_{\text {in }}=V_{\text {in }} \times I_{\text {in }} \\
& P_{\text {out }}=V_{\text {out }} \times I_{\text {out }}
\end{aligned}
$$

Pengujian efisiensi DC Chopper Buck dapat dilihat pada tabel 6. Dari tabel terlihat bahwa efisiensi rata-rata dari DC Chopper Buck masih diatas $80 \%$. 
Tabel 6 Pengujian Efisiensi DC Chopper Buck

\begin{tabular}{cccccc}
\hline $\begin{array}{c}\text { Duty cycle } \\
(\%)\end{array}$ & $\mathrm{V}_{\text {in }}(\mathrm{V})$ & $\begin{array}{c}\mathrm{I}_{\text {in }} \\
(\mathrm{A})\end{array}$ & $\begin{array}{c}\mathrm{V}_{\text {out }} \\
(\mathrm{V})\end{array}$ & $\mathrm{I}_{\text {out }}(\mathrm{A})$ & Efisiensi (\%) \\
\hline 10 & 298 & 0,01 & 31,2 & 0,08 & 83,75 \\
20 & 297,7 & 0,03 & 60,3 & 0,14 & 94,52 \\
30 & 297,4 & 0,05 & 90 & 0,16 & 96,83 \\
40 & 297,2 & 0,07 & 120 & 0,17 & 98,05 \\
50 & 297 & 0,10 & 150,6 & 0,19 & 96,34 \\
60 & 296,8 & 0,13 & 180,2 & 0,21 & 98,07 \\
70 & 296,6 & 0,16 & 209,3 & 0,22 & 97,02 \\
\hline
\end{tabular}

Hubungan antara efisiensi dan duty cycle dapat diilihat pada grafik gambar 9.

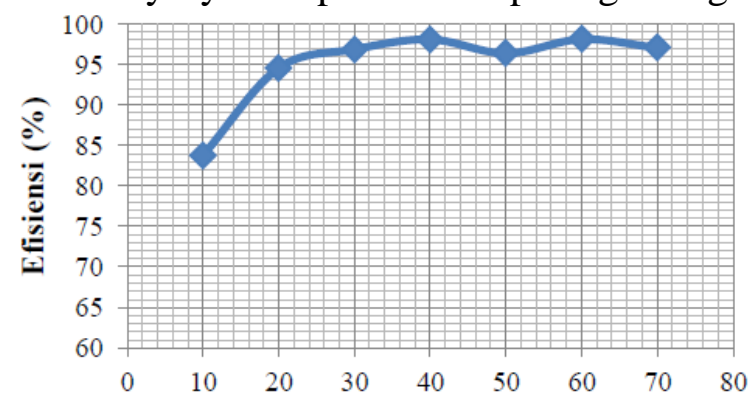

Duty Cycle (\%)

Gambar 9. Grafik efisiensi terhadap duty cycle.

\section{Pengujian DC Chopper Buck dengan beban dominan induktif}

Pengujian ini dilakukan bertujuan untuk mengetahui tegangan masukan, tegangan keluaran, arus masukan dan arus keluaran dari DC Chopper Buck pada saat dibebani beban dominan induktif $(\mathrm{R}+\mathrm{L})$. Hasil pengujian DC Chopper buck converter dapat dilihat pada tabel 7. berikut :

Tabel 7 Hasil pengujian DC Chopper Buck dengan beban

\begin{tabular}{|c|c|c|c|c|}
\hline $\begin{array}{c}\text { Duty cycle } \\
(\%)\end{array}$ & $\operatorname{Vin}(V)$ & $\operatorname{lin}(A)$ & Vout (V) & lout $(A)$ \\
\hline 10 & 297,2 & 0,02 & 30,6 & 0,15 \\
\hline 20 & 296,6 & 0,04 & 61,2 & 0,16 \\
\hline 30 & 296 & 0,05 & 90,8 & 0,16 \\
\hline 40 & 295,9 & 0,07 & 120,6 & 0,17 \\
\hline 50 & 295,6 & 0,10 & 150,6 & 0,19 \\
\hline 60 & 295,4 & 0,13 & 181,3 & 0,20 \\
\hline 70 & 295 & 0,16 & 210,5 & 0,22 \\
\hline
\end{tabular}

Hasil pengujian pada rangkaian DC Chopper Buck pada semua nilai variasi duty cycle ditunjukkan pada Tabel 8 berikut.

Tabel 8 Hasil pengujian tegangan keluaran beban dominan induktif

\begin{tabular}{ccccc}
\hline Duty cycle & Tegangan & \multicolumn{3}{c}{ Tegangan Keluaran (V) } \\
\cline { 3 - 5 }$(\%)$ & Masukan (V) & Pengukuran & Perhitungan & Simulasi \\
\hline 10 & 297,2 & 30,6 & 29,72 & 29,72 \\
20 & 296,6 & 61,2 & 59,44 & 59,32 \\
30 & 296 & 90,8 & 88.80 & 88,81 \\
40 & 295,9 & 120,6 & 118,36 & 118,36 \\
50 & 295,6 & 150,6 & 147,8 & 147,8 \\
60 & 295,4 & 181,3 & 177,24 & 177,24 \\
70 & 295 & 210,5 & 206,5 & 206,5 \\
\hline
\end{tabular}




\section{Pengujian parasitic pada beban dominan induktif}

Tabel 9 menunjukan perbandingan nilai tegangan antara hasil pengukuran, simulasi teoritik dan parasitik.

Tabel 9 Perubahan Nilai Resistansi Pada Simulasi

\begin{tabular}{|c|c|c|c|c|c|c|c|}
\hline \multirow{2}{*}{$\begin{array}{l}\text { Duty } \\
(\%)\end{array}$} & \multicolumn{2}{|c|}{ Nilai Nyata } & \multicolumn{2}{|c|}{ Nilai Asumsi } & \multicolumn{3}{|c|}{ Tegangan Keluaran (V) } \\
\hline & $\begin{array}{c}\mathrm{R} \\
(\Omega)\end{array}$ & $\begin{array}{c}\mathrm{L} \\
(\mathrm{mH})\end{array}$ & $\begin{array}{c}R \\
(\Omega)\end{array}$ & $\underset{(\mathrm{mH})}{\mathrm{L}}$ & $\begin{array}{c}\mathrm{V} \\
\text { ukur }\end{array}$ & Teoritik & Parasitik \\
\hline 10 & 2,77 & 1,6 & 150 & 1,6 & 30,6 & 29,72 & 30,1 \\
\hline 20 & 2,77 & 1,6 & 150 & 1,6 & 61,2 & 59,32 & 60,25 \\
\hline 30 & 2,77 & 1,6 & 150 & 1,6 & 90,8 & 88,81 & 90,13 \\
\hline 40 & 2,77 & 1,6 & 150 & 1,6 & 120,6 & 118,36 & 120,05 \\
\hline 50 & 2,77 & 1,6 & 150 & 1,6 & 150,6 & 147,8 & 150,8 \\
\hline 60 & 2,77 & 1,6 & 150 & 1,6 & 181,3 & 177,24 & 180,8 \\
\hline 70 & 2,77 & 1,6 & 150 & 1,6 & 210,5 & 206,5 & 210,2 \\
\hline
\end{tabular}

Selisih nilai tegangan ini terjadi akibat nilai-nilai resistansi parasitik yang terdapat pada tiap titik komponen, terutama komponen L dan jalur konduksi ketika rangkaian dioperasikan secara bersama.

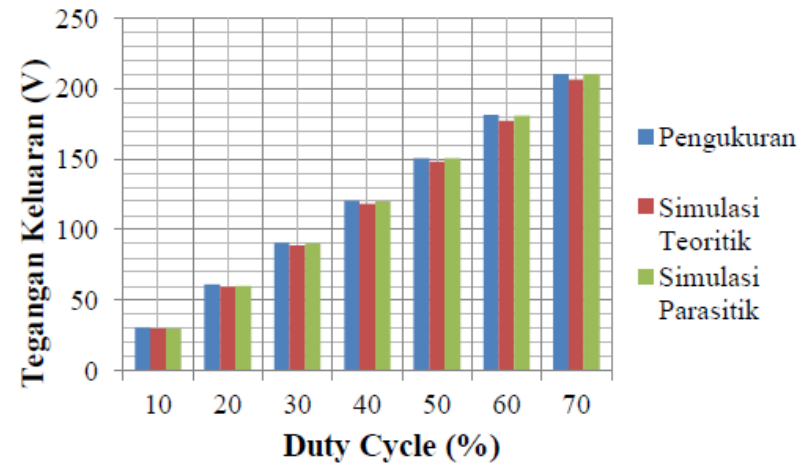

Gambar 10. Grafik perbandingan nilai tegangan pengukuran, simulasi dan teori parasitic

\section{Pengujian efisiensi DC Chopper Buck beban dominan induktif}

Efisiensi DC Chopper Buck dapat dicari dengan cara menghitung perbandingan daya input (Pin) dan daya output (Pout) pada DC Chopper Buck pada masing - masing percobaan, dengan menggunakan persamaan berikut :

$$
\eta=\frac{P_{\text {out }}}{P_{\text {in }}} \times 100 \%
$$

Dimana:

$$
\begin{aligned}
& \mathrm{P}_{\text {in }}=\mathrm{V}_{\text {in }} \times \mathrm{I}_{\text {in }} \\
& \mathrm{P}_{\text {out }}=\mathrm{V}_{\text {out }} \times \mathrm{I}_{\text {out }}
\end{aligned}
$$

Pengujian efisiensi DC Chopper Buck dapat dilihat pada tabel 10. Dari tabel terlihat bahwa efisiensi rata-rata dari DC Chopper Buck masih diatas $70 \%$.

Tabel 10 Pengujian Efisiensi DC Chopper Buck

\begin{tabular}{cccccc}
\hline $\begin{array}{c}\text { Duty cycle } \\
(\%)\end{array}$ & $\mathrm{V}_{\text {in }}(\mathrm{V})$ & $\begin{array}{c}\mathrm{l}_{\text {in }} \\
(\mathrm{A})\end{array}$ & $\begin{array}{c}\mathrm{V}_{\text {out }} \\
(\mathrm{V})\end{array}$ & $\mathrm{l}_{\text {out }}(\mathrm{A})$ & $\begin{array}{c}\text { Efisiensi } \\
(\%)\end{array}$ \\
\hline 10 & 297,2 & 0,02 & 30,6 & 0,15 & 77,22 \\
20 & 296,6 & 0,04 & 61,2 & 0,16 & 82,53 \\
30 & 296 & 0,05 & 90,8 & 0,16 & 98,16 \\
40 & 295,9 & 0,07 & 120,6 & 0,17 & 98,98 \\
50 & 295,6 & 0,10 & 150,6 & 0,19 & 96,80 \\
60 & 295,4 & 0,13 & 181,3 & 0,20 & 94,42 \\
70 & 295 & 0,16 & 210,5 & 0,22 & 98,11 \\
\hline
\end{tabular}


Dari Tabel 6 dapat disajikan grafik hubungan duty cycle dengan efisiensi dalam Gambar 11 berikut ini.

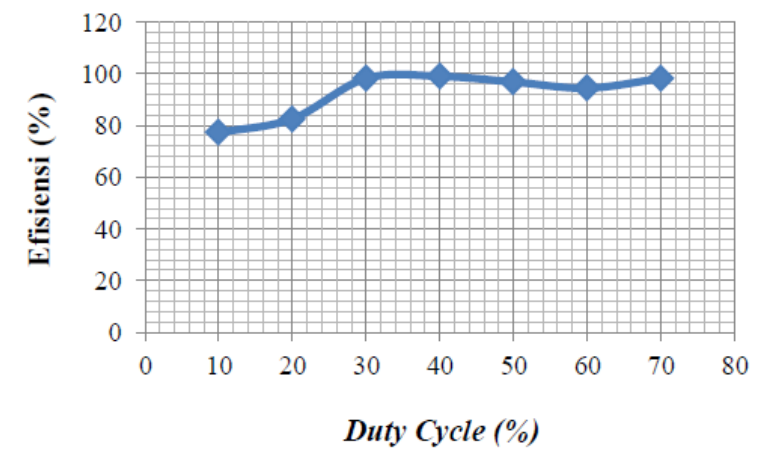

Gambar 11. Gambar 9. Grafik efisiensi terhadap duty cycle.

\section{KESIMPULAN}

Berdasarkan pada perancangan, pengujian dan analisa yang telah dilakukan didapatkan kesimpulan sebagai berikut:

1. Pembuatan perangkat keras DC chopper buck telah berhasil dengan sumber penyearahan tegangan AC jala-jala satu fasa dan dapat menghasilkan tegangan sebesar 30VDC pada duty cycle $10 \%$ sampai 210 VDC pada duty cycle $70 \%$ dengan beban $100 \Omega$.

2. Perbedaan besar nilai sumber tegangan $\mathrm{AC}$ penyearah rangkaian daya antara osiloskop dan multimeter sebesar 1 Volt dan sumber tegangan AC penyearah rangkaian kontrol sebesar 0,2 Volt.

3. Perbedaan besar nilai sumber tegangan DC penyearah rangkaian daya antara osiloskop dan multimeter adalah 0 Volt (sama) sedangkan pada sumber tegangan DC penyearah rangkaian kontrol sebesar 1,17 Volt.

4. Pada pengujian DC chopper buck beban resistif $100 \Omega$, nilai tegangan keluaran setiap duty cycle (10\%-70\%) antara pengukuran, perhitungan, dan simulasi terdapat perbedaan rata-rata sebesar $14,17 \%$.

5. Pada pengujian DC chopper buck beban dominan induktif, nilai tegangan keluaran setiap duty cycle (10\%-70\%) antara pengukuran, perhitungan, dan simulasi terdapat perbedaan rata-rata sebesar $14,24 \%$.

6. Setiap kenaikan duty cycle $10 \%$ pada beban resistif dan dominan induktif, tegangan masukan mengalami penurunan rata-rata sebesar 0.23 Volt dan 0.36 Volt. Hal ini disebabkan karena kenaikan arus masukan di setiap kenaikan duty cycle sesuai dengan hokum kekekalan daya.

7. Efisiensi yang dihasilkan DC chopper buck dipengaruhi oleh besar beban. Semakin kecil beban yang terpasang pada DC chopper buck, maka semakin rendah efisiensi yang dihasilkan.

8. Efisiensi tertinggi yang dihasilkan DC chopper buck beban resistif $40 \Omega, 100 \Omega$, dan $300 \Omega \mathrm{m}$ masing- masing sebesar 98,08\%,97,18\%, dan 90,90\%.

\section{DAFTAR PUSTAKA}

[1]. Rashid, M, Power Electronics Circuit, Device, and Aplication 3rd, Prentice-Hall International Inc, 2011.

[2]. Daniel W. Hart, "Introduction to Power Electronics, "Printice-Hall International, International Edition, 1997. 
[3]. Kim, Yong-Jun dan Mark G. Allen, Integrated Solenoid- Type Inductors for High Frequency Applications and Their Characteristics, Samsung Electronics CO.,Ltd, Suwon City, Korea, 1998.

[4]. Reungsark, Manasoontorn dan Howimanporn Suppachai, Comparison of Continues Conduction Mode (CCM) and Discontinues Conduction Mode (DCM) in Omni Robot Power Supply, University of Tecnology Phra Nakon 10300, Bangkok, Thailand, 2010.

[5]. Mohan, Ned, Power Electronics A First Course, USA, 2012

[6]. Kazimierczuk, Marian K. - Pulse-width Modulated DCDC Converters, John Wiley \& Sons. Ltd, 2008

[7]. Nihal, Kularatna, Power Electronics Design Handbook-Low Power Components and Applications, Reed Elsevier, 1998.

[8]. Tumbur, Francisco, Analisis Pengaruh Penggunaan DC Chopper terhadap Harmonik dan Faktor Daya Komponen Penyearah, Semarang, Universitas Diponegoro.

[9]. Setiawan, Eko, Penggunaan Konverter Jenis Buck dengan Pemutus Tegangan Otomatis Untuk Pengisian Akumulator, Universitas Diponegoro, 2014.

[10]. Prasetyawan, Mahadi, Modul Praktikum Penyinaran Sebagian Dan Penuh Pada Photovoltaic Jenis Monocristalline. Universitas Diponegoro, 2014.

[11]. Mahartoto Pratama, Gigih, Analisis Perbandingan Hasil Operasi CCM Dan DCM Pada DC Chopper Tipe Cuk, Universitas Diponegoro, 2014.

[12]. Simare mare, Ronny, Pembuatan Modul Perangkat Keras DC Chopper Konfigurasi Buck Dan Boost, Universitas Diponegoro, 2006.

[13]. Mubarok, Fajar Romi Al, Rancang Bangun Modul Perangkat Keras Konveyor Berbasis Programmable Logic Controller, Universitas Diponegoro, 2014.

[14]. Vernandez, Aggie Brenda, Perancangan konverter DC-DC Buck Berbasis Mikrokontroler, Universitas Diponegoro, 2015. 